\title{
Self-Help Groups (SHGs) and Women Empowerment: A Study in Cooch Behar District of West Bengal, India
}

\author{
Rema Das ${ }^{1}$ and P.K. Pal ${ }^{2}$ \\ ${ }^{1}$ Assistant Professor-cum-Junior Scientist, Department of Agricultural Extension, Rabindra Nath Tagore Agriculture College, \\ Deoghar, BAU, Kanke, Ranchi, Jharkhand, India \\ ${ }^{2}$ Professor in Agril. Extension and Director of Extension Education, Uttar Banga Krishi Viswavidyalaya, PO. Pundibari, Dist. Cooch \\ Behar, West Bengal, India
}

"Corresponding author: pkpalubkv@gmail.com

Received: 14 Jan., $2020 \quad$ Revised: 17 Apr., $2020 \quad$ Accepted: 29 May, 2020

\begin{abstract}
Empowerment is an abstract, multi- dimensional and multi-level concept that can be both a process and outcome. It can be defined as the process of increasing the assets and capabilities of individuals or groups to make purposive choices and to transform those choices into desired actions and outcomes. A Self Help Group (SHG) is a small economically homogenous affinity group of 10 to 20 persons who come together to save small amounts regularly, mutually agree to contribute to a common fund, have collective decision making, or resolve conflicts through collective leadership and mutual discussion. The present study was undertaken in Cooch Behar district of West Bengal, India to assess the impact of Self-Help Groups (SHGs) on empowerment of women. 60 SHG members and 30 non-members were selected from 10 villages from Cooch Behar-I and Cooch Behar-II blocks of the district. A pre-tested schedule was employed to collect the relevant information by personal interview method. To assess and compare between the SHG and non-SHG groups, an Empowerment Status Index (ESI) was developed for the study with different indicators of empowerment. Indicators were selected from the recommendations of different authors. From the study it was found that the empowerment status of the SHG members was higher than the non-members and empowerment is positively correlated with the efficiency of the group.
\end{abstract}

Keywords: Empowerment, Self-Help Groups, Empowerment Status Index

Empowerment has become an important tool for enabling marginalized individuals like women and poor to gain access to resources and to value their own experience. Empowerment is an abstract, multi- dimensional and multi-level concept that can be both a process and outcome (Page and Czuba, 1999). It can be defined as the process of increasing the assets and capabilities of individuals or groups to make purposive choices and to transform those choices into desired actions and outcomes. Thus, it is the process of acquiring the ability to make strategic life choices in a context where this ability has previously been denied. The core elements of empowerment have been defined as agency (the ability to define one's goals and act upon them), awareness of gendered power structures, selfesteem and self-confidence (Kabeer, 2001).

How to cite this article: Das, R. and Pal, P.K. (2020). Self-Help Groups (SHGs) and Women Empowerment: A Study in Cooch Behar District of West Bengal, India. International Journal of Inclusive Development, 6(1): 01-05.

Source of Support: None; Conflict of Interest: None 
A Self-Help Group (SHG) is a small economically homogenous affinity group of 10 to 20 persons who come together to save small amounts regularly, mutually agree to contribute to a common fund, have collective decision making, or resolve conflicts through collective leadership and mutual discussion. The basic principle of the SHGs are group approach, mutual trust, organisation of small and manageable groups, group cohesiveness, spirit of thrift, demand based lending, collateral freeness, women friendly loan, peer group pressure in repayment, skill development, training, capacity building and empowerment (Lalitha, 1995). Women and SHGs in many parts of the country have achieved success in bringing the women to the main stream of decision making. The SHG in our country has become a source of inspiration for women's welfare. Formation of SHG is a viable alternative to achieve the objectives of rural development and to get community participation in all rural development programmes. SHG is also a viable organized set up to disburse micro credit to the rural women and encouraging them together into entrepreneurial activities. According to Chiranjeevilu (2003), women have developed abundant self-confidence and self-esteem through SHG movement which tackles poverty, social and gender discrimination and makes them self sustaining. SHGs instil necessary skills to produce a product, manage funds, organize the operations of enterprises and links women to the market and government departments which improved their position at home and in the community (Rajapriya, 2008). Thus, SHG has been an instrument now a days to empower and mainstreaming women by making them capable of accessing resources, more conscious about their right, more reciprocating and valuing others.

District Cooch Behar has 15553 registered Self-Help Groups under SGSY except other SHGs formed under Watershed Development Projects, different NGOs or by other developmental interventions (Source: www.coochbehar.nic.in).

In the said backdrop, the present study was undertaken to seek answer of the question that, whether the status of group efficacy has any bearings with the level of empowerment of women group members of Cooch Behar with the following specific objectives: (i) To assess the efficiency of different SHGs in Cooch Behar district of West Bengal.

(ii) To study the social empowerment status of the women SHG members in Cooch Behar district of West Bengal.

(iii) To assess the impact of Self-Help Groups (SHGs) on empowerment of women.

\section{METHODOLOGY}

\section{Area of study and the respondents}

The present study was conducted Coochbehar-I and Coochbehar-II blocks in Coochbehar district of West Bengal. The blocks were purposively selected for the study considering the number of Women SelfHelp Groups and other demographic characters. From each block 5 villages were randomly selected and from each village 3 women self-help groups were randomly selected and from each group 2 non-leader members were selected, thus, 60 SHG members were selected. Moreover, from the same villages, 30 non-SHG women were also selected for the study. In this way total 90 respondents constitute the sample for this study.

\section{Measuring group efficiency and empowerment status}

Group efficiency and empowerment were measured through development of indices. Two indices namely Group Efficiency Index (GEI) and Empowerment Status Index (ESI) were developed in this study with some selected indices. The indices were selected through experts' opinion following scale construction methodology.

\section{Indicators selected for extracting GEI and scale values for each indicator}

The indicators selected were: (a) Frequency of Meeting [Scale values: No (0), Irregular/when required (1), Once in a month (2), More than once in a month (3)]; (b) Whether taken any productive activity [No (0), Yes (1)]; (c) Asset generation [No (0), Nominal (1), Near about ₹ 5000 (2), More than Rs. 5000 (3)]; (d) Saving and inter-loaning behavior of members [Irregular (1), By some of the members (2), Regular by all (3)]; (e) Satisfaction level being the member of the group [Dissatisfied (0), Little bit satisfied (1), Moderately satisfied (2), Highly satisfied (3)]. 


\section{Indicators selected for extracting ESI and scale values for each indicator}

The indicator selected were: (a) Possession and operation of Bank Account (A/C) [Having no A/C (0), Having $\mathrm{A} / \mathrm{C}$ but managed by husband/ son/ others (1); Having A/C and own management (2)]; (b) Mobility [Respondent was exposed to a number of situations and each situation was measured against the scale, 'Frequenly', 'sometimes' and 'never' with '2', ' 1 ' and '0' scores respectively]; (c) Information Seeking behavior [Respondent was exposed to a number of information sources and measured against the scale, 'Frequenly', 'sometimes' and 'never' with ' 2 ', ' 1 ' and ' 0 ' scores respectively]; (d) Decision-making in household matters [Respondent was exposed to a number of situations and each situation was measured against the scale, 'Frequenly', 'sometimes' and 'never' with ' 2 ', ' 1 ' and ' 0 ' scores respectively]; (e) Organisational Participation [None (0), Only 1(1), Member of 2 (2), Member of more than 2/Office bearer (3)]; (f) Self confidence level [Respondent was exposed to a number of situation statements and each situation was measured against a 5-point scale from 'strongly agree' to 'strongly disagree'].

\section{Data processing and analysis}

Processing of data: As the indicators were tested against different types of scales $(0 / 1$ or 3 -point or 5 -point), the scales were transformed to unitary value (out of 1 scale), wherever necessary by the following formula (normalisation of data):

Transformed value $=\frac{\text { Score obtained }- \text { Minimum score }}{\text { Maximum score }- \text { Minimum score }}$

Values of Indices: Average of the transformed values for all indicators for GEI and ESI were taken as GEI and ESI respectively for each individual.

For analysis of data statistical tools like mean, S.D, t-test, one-way Anova and correlation etc. were used in this study.

\section{RESULTS AND DISCUSSION}

\section{Status of group efficiency indicators for the SHGs of Cooch Behar district}

Table 1 represents the average values of the indicator variables of group efficiency. It is seen that level of asset generation and saving \& inter-loaning behavior of members are very low in achievement, whether variables like frequency of meeting, and satisfaction level being the member of the group achieved moderate level of achievement. The Groups were graded satisfactorily and achieved an average grading of 1.38 and 1.12 in Cooch Behar-I and Cooch Behar-II blocks respectively. However t-test values indicate an insignificant difference between two blocks in terms of each of the achievement in each of the indicators of group efficiency in acceptable level of significance (none of the p-value is less than 0.05). So, it can be concluded that the two blocks are homogeneous in respect of group efficiency.

Table 1: Status of Group Efficiency based on the Performance Indicators of the SHGs

\begin{tabular}{|c|c|c|c|c|c|}
\hline \multirow{3}{*}{$\begin{array}{c}\begin{array}{c}\text { Group efficiency } \\
\text { Indicators }\end{array} \\
\text { Asset generation }\end{array}$} & \multirow{3}{*}{$\begin{array}{c}\text { Range } \\
0-3\end{array}$} & \multirow{3}{*}{$\begin{array}{l}\text { Block } \\
\text { COB-1 } \\
\text { COB-2 }\end{array}$} & \multirow{2}{*}{$\begin{array}{l}\text { Mean } \\
0.08\end{array}$} & \multicolumn{2}{|c|}{ t-value p-value } \\
\hline & & & & 0389 & 699 \\
\hline & & & 0.12 & 0.309 & . \\
\hline \multirow{2}{*}{$\begin{array}{l}\text { Frequency of } \\
\text { Meeting }\end{array}$} & \multirow{2}{*}{$0-3$} & COB-1 & 1.85 & \multirow{2}{*}{0.148} & \multirow{2}{*}{.882} \\
\hline & & COB-2 & 1.79 & & \\
\hline \multirow{2}{*}{$\begin{array}{l}\text { Grading of the } \\
\text { Self-Help Group }\end{array}$} & \multirow{2}{*}{$0-2$} & COB-1 & 1.38 & \multirow{2}{*}{0.935} & \multirow{2}{*}{.354} \\
\hline & & COB-2 & 1.12 & & \\
\hline \multirow{2}{*}{$\begin{array}{l}\text { Saving and inter- } \\
\text { loaning behavior of } \\
\text { members }\end{array}$} & \multirow[b]{2}{*}{$1-3$} & COB-1 & 0.23 & \multirow[b]{2}{*}{1.537} & \multirow[b]{2}{*}{.130} \\
\hline & & COB-2 & 0.09 & & \\
\hline Satisfaction level & & COB-1 & 1.71 & & \\
\hline $\begin{array}{l}\text { being the member } \\
\text { of the group }\end{array}$ & $0-3$ & COB-2 & 1.56 & 0.796 & .429 \\
\hline
\end{tabular}

\section{Status of empowerment indicators among the members of Self Help Groups}

Table 2 depicts the mean score of each empowerment indicators used for assessing empowerment status of women members in the selected blocks. Here, empowerment has been measured in terms of self-confidence, possession and operation of bank account, utilization communication sources, decision making ability, mobility and organizational participation of the self-help group members in the study area.

Results reveal that empowerment indicators such as self-confidence score, possession and operation of bank account, communication behaviour and mobility score of the self-help group members 
Table 2: Comparative status of empowerment indicators of SHG members in study Bocks

\begin{tabular}{|c|c|c|c|c|c|}
\hline Empowerment indicators & Range & Block & Mean & t-value & p-value \\
\hline \multirow[t]{2}{*}{ Self-confidence score } & \multirow{2}{*}{ 2-6 } & COB-1 & 3.33 & \multirow{2}{*}{0.299} & \multirow{2}{*}{.766} \\
\hline & & COB-2 & 3.28 & & \\
\hline \multirow{2}{*}{$\begin{array}{c}\text { Possession and operation of Bank } \\
\text { Account }(\mathrm{A} / \mathrm{C})\end{array}$} & \multirow{2}{*}{$0-3$} & COB-1 & 1.19 & \multirow{2}{*}{1.567} & \multirow{2}{*}{.122} \\
\hline & & COB-2 & 0.74 & & \\
\hline \multirow[t]{2}{*}{ Communication Behaviour } & \multirow{2}{*}{$0-5$} & COB-1 & 2.33 & \multirow{2}{*}{0.270} & \multirow{2}{*}{.788} \\
\hline & & COB-2 & 2.24 & & \\
\hline \multirow[t]{2}{*}{ Decision making Index } & \multirow{2}{*}{$0-1$} & COB-1 & 0.59 & \multirow{2}{*}{2.445} & \multirow{2}{*}{.018} \\
\hline & & COB-2 & 0.44 & & \\
\hline \multirow[t]{2}{*}{ Mobility score } & \multirow{2}{*}{$4-18$} & COB-1 & 10.23 & \multirow{2}{*}{0.005} & \multirow{2}{*}{.996} \\
\hline & & COB-2 & 10.24 & & \\
\hline \multirow[t]{2}{*}{ Organisational participation } & \multirow{2}{*}{$1-5$} & COB-1 & 1.88 & \multirow{2}{*}{3.513} & \multirow{2}{*}{.001} \\
\hline & & COB-2 & 2.85 & & \\
\hline
\end{tabular}

Table 3: Distribution of Groups according to Efficiency

\begin{tabular}{|c|c|c|c|c|c|c|c|c|c|}
\hline \multirow{3}{*}{$\begin{array}{c}\text { Group Efficiency } \\
\text { level }\end{array}$} & \multicolumn{4}{|c|}{ Cooch Behar-I } & \multicolumn{4}{|c|}{ Cooch Behar-II } & \multirow{3}{*}{$\begin{array}{l}\text { t-test value } \\
\text { between } \\
\text { blocks }\end{array}$} \\
\hline & \multirow{2}{*}{ Freq } & \multirow{2}{*}{ Per } & \multicolumn{2}{|c|}{ GEI } & \multirow{2}{*}{ Freq } & \multirow{2}{*}{ Per } & \multicolumn{2}{|c|}{ GEI } & \\
\hline & & & Mean & SD & & & Mean & SD & \\
\hline Low & 6 & 40.00 & 0.43 & 0.082 & 9 & 60.00 & 0.45 & 0.091 & \\
\hline High & 9 & 60.00 & 0.68 & 0.048 & 6 & 40.00 & 0.67 & 0.089 & $1.14 \mathrm{NS}$ \\
\hline Pooled & 15 & 100.00 & 0.58 & 0.139 & 15 & 100.00 & 0.54 & 0.141 & \\
\hline
\end{tabular}

in both Cooch Behar-I and Cooch Behar-II Block were at per or no significant difference existed there (p-value is greater than .05 in all the cases). It is also clear that mean score of decision making index (0.59) of women members in Cooch Behar-I is higher than that $(0.44)$ of women members in Cooch Behar-II block and also p-value of decision making index $(p=.018)$ shows there is significant difference in decision making ability of self-help group members between both the blocks. On the contrary, members from Cooch Behar-II block is having higher organizational participation than the SHG members of Cooch Behar-I block, and $\mathrm{p}$-value of organizational participation $(\mathrm{p}=.001)$ shows significant difference among members of both blocks regarding their participation in various organizational activities.

\section{Level of group efficiency of Self-Help Groups in Cooch Behar}

Table 3 presents distribution of self-help groups according to their efficiency in the selected blocks. In Cooch Behar-I Block majority of the SHGs (60\%) explicates higher level of group efficiency with a pooled GEI value equalled to 0.58 .
On the contrary, in Cooch Behar-II Block, most of the SHGs $(60 \%)$ showed low level of group efficiency and pooled GEI was 0.54. From pooled data it can be concluded that group efficiency of SHGs are moderate on an average in the study areas. It also reveals that there was no significant difference regarding the group efficiency level between two blocks.

\section{Impact of group efficiency on empowerment}

The present section represents the result of empowerment according to group efficiency. Oneway ANOVA test was done to infer about the impact of GEI on ESI. Table 4 represents the empowerment status of women SHG members of Cooch Behar according to group efficiency.

In these study non SHG members explicates ESI score of 0.37 which was lower than the ESI score of both low-efficient SHG members and high-efficient SHG members viz. 0.46 and 0.55 respectively. Oneway ANOVA analysis indicates that there was significant difference in empowerment status of women in respect to the level of group efficiency. Hence, conclusion can be drawn that group efficiency has an effect on producing the differences 
Table 4: Empowerment status of women SHG members of Cooch Behar according to group efficiency

\begin{tabular}{cccccc}
\hline \multirow{2}{*}{ Group Efficiency level } & \multirow{2}{*}{$\begin{array}{c}\text { No. of sampled } \\
\text { members }\end{array}$} & $\begin{array}{c}\text { Empowerment Status Index } \\
\text { (ESI) }\end{array}$ & \multirow{2}{*}{$\begin{array}{c}\text { One-way ANOVA } \\
\text { (F-value) }\end{array}$} & p-value \\
\cline { 3 - 4 } & 30 & 0.37 & 0.055 & & \multirow{2}{*}{ Mean } \\
Non-members & 30 & 0.46 & 0.130 & 13.85 & 0.000 \\
Low-efficient group members & 30 & 0.55 & 0.175 & & \\
High-efficient group members & & & & & \\
\hline
\end{tabular}

Correlation between GEI and ESI $=0.255(p<0.05)$.

in empowerment status of women SHG members of Cooch Behar district of West Bengal. Correlation analysis confirmed this result by showing a positive and significant association between empowerment status of women and level of group efficiency. Group members with higher efficiency means members are regularly attends group meetings, generates more number of assets through taking up productive activities and very much satisfied with the group performance ultimately leads to their increasing socio-economic empowerment.

\section{CONCLUSION}

Findings of the study clearly depicts that efficiency of different Self-Help Groups is moderate on an average. The women Self-Help Group members of Cooch Behar district are moderately empowered on an average whereas the empowerment status of non-members is low to moderate. Empowerment status differs significantly according to the group efficiency levels and it has a significant positive correlation with empowerment status. So, it can be recommended that all the women should be included in the Self-Help groups to achieve empowerment among them.

\section{REFERENCES}

Chiranjeevulu, T. 2003. Empowering Women through self-help groups-Experiences in Experiment. Kurukshetra. March, 2003.

Kabeer, N. 2001. Resources Agency Achievements: Reflections on the Measurement of Women's Empowerment - Theory and Practice. SIDA Studies. No. 3.

Lalitha, N. 1995. Women Thrift and Credit Groups-Breaking the barriers at the gross roots. Peninsular Economist, $\mathbf{X I I}(2)$ : 188-195.

Page, Nanette and Czuba, Cheryl E. 1999. Empowerment: what is it? Journal of Extension, 37(5).

Rajapriya, M. 2008. Role of Self-Help Group women in Value base Emancipation. Social Welfare, 55(06). 
